\title{
THE ENTRIES AND ETHICS OF ORATORS AND PAUL (1 THESSALONIANS 2:1-12) ${ }^{1}$
}

\author{
Bruce W. Winter
}

\section{Summary}

Did Paul take cognizance of the 'entry' conventions and the professional behaviour associated with the highly skilled and much admired public orators of his day? In 1 Thessalonians 2:1-12 he recounts the nature of his original 'entry' to Thessalonica. His autobiographical account is framed in the light of the 'entry' protocol and is also contrasted with the ethics of first century orators and sophists. Paul's concern is that his original 'entry' and projected re-entry might be perceived by Thessalonian Christians in these secular categories.

The world of Paul's day was deeply enamoured with the public oratory of the virtuoso rhetors known as 'sophists'.2 Because Christianity spread its message in part by means of speeches, the canons of rhetoric would have been used to judge its preachers' performances by at least some of their hearers in the East of the Roman empire. Christian missionaries themselves needed to determine their attitude to the use of classical rhetoric for preaching. 3

${ }^{1}$ This paper owes its genesis to Professor R.F. Hock who first drew my attention to the similarity between the cultural background of 1 Cor. 2:1-5 discussed in my thesis, Philo and Paul among the Sophists: Hellenistic Jewish and Christian Responses (PhD Macquarie University 1988) and that of 1 Thess. 2:1-12. This article is a revision of the paper read in the New Testament and the Graeco-Roman World seminar at the 1992 International Congress for the Study of Religion, Melbourne.

2They were accomplished public orators with a large public following and usually set up schools to train young men in the art of rhetoric. For discussion see G.W. Bowersock, Greek Sophists in the Roman Empire (Oxford 1969) 13, and E.L. Bowie, 'Greeks and their Past in the Second Sophistic', Past and Present 46 (1970) 5. For a more recent critical assessment of Bowersock's definition see G. Anderson, 'The pepaideumenos in Action: Sophists and their Outlook in the Early Empire' ANRW II.33.1 (1989) 87ff. and his 'The Second Sophistic: Some Problems of Perspective', in D.A. Russell (ed.), Antonine Literature (Oxford, Clarendon Press 1990) 92-4 where he wishes the term to cover certain literary figures.

3This has been explored by A.D. Litfin, St. Paul's Theology of Proclamation: An investigation of 1 Corinthians 1-4 in the Light of Greco-Roman Rhetoric 
The early preachers also had to clarify in advance whether they would observe any of the conventions related to the initial 'coming' of orators into a city in the first century and their professional conduct as teachers and declaimers. The 'entry' was crucial because by it a reputation could be secured in public life and orators could recruit fee-paying pupils or 'disciples' as they were often called. Did Paul in 1 Thessalonians 2:1-12 recount the nature of his original 'entry' into Thessalonica in the light of these established conventions and if so, why did he do it?

It is proposed to examine these questions concerning Paul's 'coming' by (I) exploring it in the light of the conventions surrounding the initial visit or 'entry' of a virtuoso orator into a city whereby one secured a place there in 'public life' ( $\pi 0 \lambda \imath \tau \varepsilon i \alpha)$ and also in 'education' ( $\pi \alpha \imath \delta \varepsilon i \alpha)$, (II) rehearsing criticisms of the professional conduct of these highly influential public figures, (III) examining Paul's autobiographical account of his motives and conduct on his 'entry', (IV) comparing briefly his autobiographical description of his coming to Corinth with the entry of orators (1 Cor. 2:1-5, 3:1ff.), and (V) seeking to ascertain the reason why he should have so described his entry in 1 Thessalonians 2:1-12. This investigation will seek to demonstrate that Paul reacted against the sophistic conventions of the orators of his day and this had a significant bearing on his modus operandi as a missionary and an apostle. If correct, it questions any need to argue that Paul was defending himself against the criticisms of his compatriots, be they Gnostics or other Christians, 4 or that he was cloaking himself in the guise of the ideal philosopher. ${ }^{5}$

(unpublished D.Phil, University of Oxford 1983) and my own thesis cited in n. 1 and forthcoming (Tübingen, J.C.B. Mohr [Paul Siebeck] 1993).

${ }^{4}$ For surveys of views expressed see R.F. Collins, Studies in The First Letter to the Thessalonians, Bibliotheca Ephemeridum Theologicarum Lovaniensium LXVI (Leuven, Leuven University Press 1984) 23-24 and his own view that it belongs to the genre of 'personal confession', 184-5; $R$. Jewett, The Thessalonian Correspondence: Pauline Rhetoric and Millenarian Piety (Philadelphia, Fortress Press 1986) 149-50 and his argument for the

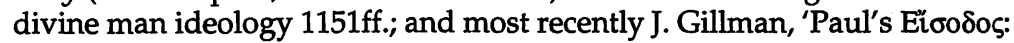
The Proclaimed and the Proclaimer (1 Thes 2,8)', in R.T. Collins (ed.), The Thessalonian Correspondence, Bibliotheca Ephemeridum Theologicarum Lovaniensium LXVI (Leuven, Leuven University Press 1990) 62-70 who 


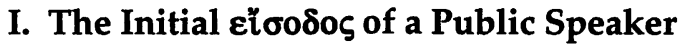

The coming or 'entry' of an orator to a city could be something of an event in the early empire. For example, Dio Chrysostom records the enthusiastic welcome he received and the attention accorded to him when he visited

the great cities of the empire-escorted with much enthusiasm $(\zeta \tilde{\eta} \lambda \circ \varsigma)$ and honour ( $\phi \imath \lambda \circ \tau \imath \mu i \alpha)$ the recipients being grateful for my presence and begging me to address them and advise them, and flocking about my doors from early dawn. . 6

His account reflects just some of the conventions associated with the initial visit.

Organisation and Invitations: Aristides records not only that the most distinguished young men offered themselves to me as students' on his entry to Smyrna, but also there was the planning and notification of the lecture and the issuing of invitations. These he notes were 'exactly fulfilled in every detail'. ${ }^{7}$ He records that when he came to that city there was a rival orator from Egypt whom he describes disparagingly as 'a certain little Egyptian'. He had given three days' prior notice of his performance. 8 Not to be outdone, Aristides hastily arranged a lecture for 10 am that very day as a result of 'a dream'. 'An advertisement was put out' and his impromptu appearance hastily arranged.

Locations: Aristides made use of the bouleterion in Smyrna, while his Egyptian rival booked the Odeion. Lecture halls were popular as were temple precincts and theatres. 9 Lucian describes the value of acoustics in a lecture hall for the orator's voice. 10

argues for both an apologetic and paraenetic purpose with Paul preserving the gospel truth and his own integrity as its apostle.

${ }^{5}$ A. Malherbe, Paul and the Thessalonians (Philadelphia, Fortress 1980) and Paul and the Popular Philosophers (Philadelphia, Fortress 1989) ch. 3.

6Dio Chrysostom, Or. 47.22. Cf. the similar visit of Aristides to Smyrna in c. AD 176, Or. 51.29-34 cited by D.A. Russell, Greek Declamations (Cambridge, CUP 1983) 76.

7Or. 51.29.

${ }^{8}$ Or. 51.34 .

${ }^{9}$ D.A. Russell, op. cit., 76.

10 De domo, 1.3ff. 
Audiences: One thousand or more were recorded attending an orator's speech.11 Favorinus records that at his initial 'entry' 'women and children attended' as well as the men of Corinth.12 This is believed to be 'the traditionally derisory number' which was 17 and this was all that the Egyptian could attract in Smyrna. ${ }^{13}$

The preliminary speech (a) the dialexis: A preliminary speech was expected of an orator and technical terms used to describe-

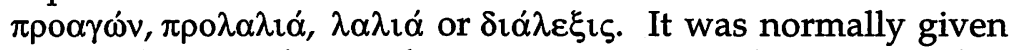
sitting down and was 'the curtain raiser' to the main performance. 'It was ordinarily a polite introduction, courteous to the audience, not necessarily modest but at least disarming' ${ }^{14}$ It was demanding for as Anderson states it 'was a matter for special skill calling for concentration of nerve. . .in unfamiliar circumstances before an untried audience' .15

The $\delta i \alpha \dot{\lambda} \varepsilon \varepsilon \xi 1 \varsigma$ had developed its own art form and was expected to be adhered to. ${ }^{16}$ Philostratus comments on such preliminary speeches in Athens. He ceñsures the famous sophist, Polemo, for his arrogance in Athens because he broke with convention by abandoning it-'he did not make an oration about his own renown'17-and 'this was simply not professional'.18

The preliminary speech $(b)$ an encomium: Philostratus however approves of the encomium delivered in Athens by Alexander of Seleuca. It was 'the appropriate length. . for it was like the epitome of a Panathenaic oration'.19 Furthermore he apologised for not having visited this city before. Not so Polemo. He gave no encomium 'when there were so many things that one might say of the Athenians'.20 Philagrus of Cilicia was deemed to have failed in spite of his reputation

${ }^{11 E p i c t e t u s, ~ I I I .23 .19 ~ a n d ~ D . A . ~ R u s s e l l, ~ o p . ~ c i t ., ~ 76, ~ G . ~ A n d e r s o n, ~ " T h e ~}$ pepaideumenos in Action', 91.

12Dio Chrysostom, Or. 37.33.

${ }^{13}$ D.A. Russell, op. cit., $76, \mathrm{n}$. 16 for discussion.

${ }^{14}$ D.A. Russell, op. cit., 77.

${ }^{15} \mathrm{G}$. Anderson, 'The pepaideumenos in Action', 92.

${ }^{16}$ D.A. Russell, op. cit., 78 for evidence.

17Philostratus, Lives of the Sophists, \# 535.

${ }^{18} \mathrm{G}$. Anderson, Philostratus (London, Croom Helm 1986) 45.

19Philostratus, Lives of the Sophists, \# 572.

20Philostratus, Lives of the Sophists, \# 535. 
because he introduced a lament for his deceased wife into his encomium and that ran counter to the convention.

The topic and the speech: Following the encomium, the audience was invited to nominate a topic or topics upon which they wished the orator to declaim-'give me themes for improvisation' ( $\delta$ ó $\tau \varepsilon \pi \rho \circ \beta \lambda \eta \mu \alpha \tau \alpha)$ was the customary request. ${ }^{21}$ These would be put to a vote if the need arose. It was open to the rhetor to rise up immediately and declaim which some did. Others chose to return a day later to deliver their oration. Improvisation was not always genuine, for a member of the audience might be primed to nominate the topic-the proposal from the floor might easily be stage-managed.22

The oration had by convention to be original. The resurrection of a previous one was not acceptable. There was the famous incident in Athens where Philagoros declaimed on a topic which had been nominated by the staunch disciples of a rival orator, the famous Herodes Atticus. The former orator had already declaimed on the topic, and indeed had published that speech in another city. When he began to declaim the rival disciples chanted back the speech from the text before them. While he was to go on to secure the chair of rhetoric in Rome, this chance of establishing himself in Athens was immediately dashed because he broke with convention. ${ }^{23}$

The rewards: The audience voted by three means. The orator might secure its sons as pupils for his intention was to set up a school in the city. The orator's schools provided the rigorous training in oratory essential for any young man who wished to pursue a career in forensic rhetoric or to take his place in the

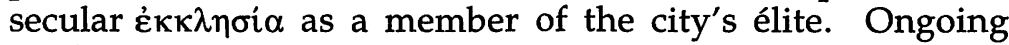
public declamations were also given to maintain his reputation.

In addition the orator's services could also be secured by a citizen engaged in litigation for which professional fees were charged.24 Citizenship might also be awarded thereby

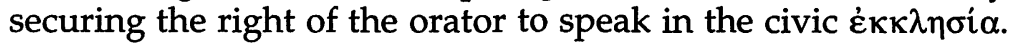
Their services could also be in demand to head an embassy to the governor of a province or the emperor himself for the

21 Ibid., \# 529, 574, 579.

${ }^{22}$ D.A. Russell, op. cit., 80.

${ }^{23}$ Ibid., 80-1.

${ }^{24}$ G.A. Kennedy, The Art of Rhetoric in the Roman World (Princeton, Princeton University Press 1972) 437. 
purpose of securing civic favours, or defending privileges already granted to a city. 25

In summary, the 'entry' was planned, the invitations issued, the preliminary speech provided the opportunity to praise one's past, the encomium praised the audience whose good will had to be secured, the topic was settled, and the speaker rose up to declaim. The outcome meant either wealth and fame in $\pi 0 \lambda_{\imath} \tau \varepsilon i \alpha$ and $\pi \alpha \imath \delta \varepsilon i \alpha$ and in the courts, or, of course, rejection.

\section{Criticisms of the Orator's Professional Ethics}

Professional orators had long attracted criticism because of what was judged to be their unethical conduct. These had by no means abated in Paul's day. Extant sources leave us with the impression that in the first century with the unfolding of the 'Second Sophistic' criticisms had only intensified.

Money: Dio Chrysostom who distanced himself from the virtuoso rhetors introduced his encomium with this apologia'Gentlemen, I have come before you not to display my talents as a declaimer, nor because I want money from you, nor because I expect praise. ${ }^{26} \mathrm{He}$ sought to disarm his audience by renouncing the standard criticisms made of the sophists of his day, to which were also added 'flattery' and 'deception'.

A number of observers from the early empire were to reflect Plato's criticism of the virtuoso orators-'Can it be. . that the sophist is really a sort of merchant or dealer in provisions on which the soul is nourished. . hawking them about to any old purchaser who desires them'.27 Philo also comments that they 'sell their tenets and arguments like any bit of merchandise in the market':28 In a first century Cynic epistle, Socrates denounces them because of their 'little regard for education...[they] concern themselves with making money... they zealously pursue wealth. . .[and] the luxurious

${ }^{25}$ On sophists going to embassies see E.L. Bowie 'The Importance of Sophists', Yale Classical Studies 27 (1982) 29-59.

26Or. 35.1

27Protagorus 313c-d. For discussion see G.B. Kerferd, The Sophistic Movement (Cambidge, CUP 1981) 25-6.

${ }^{28}$ Mos. II.212. 
life'.29 Neilus, a student of rhetoric in Alexandria was to write home to his father in the time of Vespasian complaining of the exorbitant school fees being charged by sophists. ${ }^{30}$ Dio Chrysostom noted the way that sophists looked on their pupils

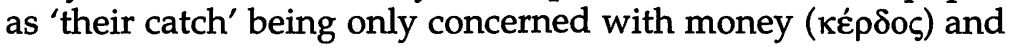
glory $(\delta o ́ \xi \alpha)$.

On the charging for public declamations the way of the orators is contrasted with that of the philosopher: 'I give my philosophical instruction in public, and equally allow the one who has much and the one who does not to hear me'.31

With the lifting of the embargo for charging fees for litigation during the Principate of Claudius, forensic orators clearly touted for business. ${ }^{32}$ They sought clients among the crowds at the Isthmian games. Of this Dio Chrysostom was to complain of 'the innumerable lawyers perverting justice'

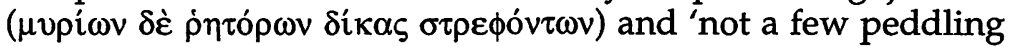
what each of them happened to have'.33 The promise of success in civil litigation was important to a client as it was the means by which one secured superiority in status and power over an opponent in civic life. ${ }^{34}$ It also quickly established the ability of a young orator especially if he were to take on a case against a leading person in the city.

Plutarch also noted that some rhetors and sophists were motivated by pecuniary interests. ${ }^{35}$ Orators clearly needed to defend themselves against the charge of greed. Some argued that people only value the things for which they pay and therefore it was not improper to charge fees. ${ }^{36}$

Reputation ( $\delta \dot{o} \xi \alpha$ ): The official honours which could be given to an orator were considerable. Polemo received imperial honours, and Nicetes from the Neronean era was awarded civic

${ }^{29}$ A. Malherbe (ed.), Cynic Epistles (Missoula, Scholars Press 1977) 1.4, 6.10, 6.1-2

30P. Oxy. 2190 ll. 30-2.

${ }^{31}$ Cynic Epistles 1.2.

32Tacitus, Ann. 11.7, and G.A. Kennedy, op. cit., 437.

${ }^{33} \mathrm{Or} .8 .9$.

${ }^{34}$ For the evidence see my 'Civil Litigation in Secular Corinth and the Church: The Forensic Background to 1 Corinthians 6:1-8', NTS 37 (1991) $559-72$.

${ }^{35}$ Moralia 131a.

36Philostratus, Lives of Sophists, \# 494. 
honours. ${ }^{37}$ Favorinus had been cast in bronze by the Corinthian citizens, in front of the library in the forum, and public inscriptions in that Roman colony also recorded the names of its orators who were honoured for posterity. 38

The adulation of the sophists was noted with disgust by Dio Chrysostom who calls them 'gorgeous peacocks lifted aloft on the wings of the glory and their disciples'. 39 Plutarch also refers to a sophist who was much admired for his many disciples. 40 The 'prestige of the sophists began with his pupils', 41 in much the same way as clients did for their patrons. It did not end there, for they not only expected their pupils to promote their achievements but did so themselves among the 'great' of their day 'in theatres or before their pupils. . .uttering loud boasts. ... 42

Praise: Epictetus derides the preoccupation with praise.

The other day when your audience gathered rather coolly, and did not shout applause, you walked out of the lecture theatre in low spirits. And again the other day when you were received with applause, you walked around and asked 'What did you think of me.' Today I had a much larger audience!. . .the figure of 500 is suggested. 'Nonsense' is the reply, 'make it 1000.' Dio never had so large an audience, how could you expect him to! 43

When a hearer asked a question after a declamation, the only response from the orator was 'but praise me!' ( $\dot{\alpha} \lambda \lambda^{\prime}$ ह̇ $\pi \alpha i v \varepsilon \sigma o ́ v$ $\mu \varepsilon)$. 'What do you mean by praise?' 'Cry "Bravo!" "Marvellous!"'44 The purpose of orators' pupils was cynically described thus by Epictetus-' they have left home, family, friends and relatives and are there simply for the purpose of crying "Bravo"'.45 It was Dio Chrysostom who was to record

37Ibid., \# 532-3.

${ }^{38}$ Or. 37.20, J.H. Kent, Corinth: Inscriptions 1926-1950; Corinth: Results 8.3 (Princeton, American School of Archaeology in Athens 1966) nos. 226, 264, 268-9.

${ }^{39}$ Or. 12.5 .

${ }^{40}$ Moralia 78.a.

${ }^{41} \mathrm{G}$. Anderson, op. cit., 49.

42Dio Chrysostom, Or. 77/78.27.

43Epictetus, III.23.19. For a summary see G. Anderson, 'The pepaideumenos in Action', op. cit., 97-8.

44Epictetus, III.23.23.

${ }^{45}$ Epictetus, III.23.32. 
that, when the virtuoso rhetors were praised their livers swelled up, and when they were not their livers shrivelled. 46

Deception: The charges levelled on this account were twofold. The first was that they could not themselves live out the virtues they taught and therefore were self-deceived. The second alleged that they engaged in the deception of their audiences because their oratorical ability had a seductive effect on their hearers.

The virtuoso rhetors prided themselves that they not only taught declamation but also the great civic virtues. Philo was to observe that 'they profess to instil in their pupils the great virtues discussing the topics of "The Social Character of Righteousness", "The Advantageous Nature of Moderation", "The Great Benefits of Piety", and "The Power of Virtue to bring Salvation"'. They also dissertate on the opposites i.e. the classical vices. 47 Philo not only lists the virtues and opposing vices they discuss, but also shows that their lives reflect the actual vices they teach against. The teaching of virtue had degenerated 'into a kind of amoral art of success' in Plato's day as in the first century. 48 In the latter period there had developed a philosophical justification of the hedonistic lifestyle which the sophists contrasted with that of their opponents whom they described as the 'so-called lovers of virtue'.49

They also seduced their audiences with the power of rhetoric. Philo, following Plato, called them 'magicians, imitators of realities. . .in the guild of false workers and jugglers' .50 The magic and the seductive influences of oratory on the audience was Philo's deep concern. He was to equate them with the Egyptians of Moses' day who engaged in the 'tricks of the

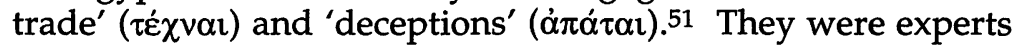

${ }^{46}$ Or. 8.33.

47Philo, Det. 72-3.

${ }^{48}$ C.J. Rowe, Plato (Brighton, Harvester 1984) 150-7

${ }^{49}$ Det. 32-4.

50Plato, The Sophist 235a, 241b. Cf. Dio Chrysostom, Or. 8.9 on orators at the 'magicians' and discussion in J. de Romilly, 'Plato and the Conjurers', Magic and Rhetoric in Ancient Greece (Cambridge, Mass. and London, Harvard University Press 1975) and W.J. Kelly, 'Rhetoric as Seduction' in K.V. Erickson (ed.), Plato: True and Sophistic Rhetoric (Amsterdam, Rodopi 1979) 513-23.

51 Som. II.40. 
in 'decoying, charming, and bewitching, their hearers' 52 Courts had been influenced for ill by these virtuoso performers.53 Philo calls them impostors, flatterers, inventors of cunning plausibilities. . .who know how to cheat and mislead, but. . have no thought for honest truth' .54 He condemns their

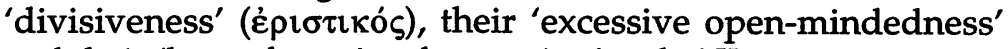
and their 'love of arguing for arguing's sake'.55

Philo laments that, in the early decades of the first century, city after city was being won over by these orators and the whole world was honouring them. 56

In conclusion, this survey has rehearsed the long standing and mainly contemporary criticisms of the professional standards of orators and also their ineffectiveness in instilling and living by those very civic virtues for which they claimed they possessed the expertise. In the next section it will be argued that when Paul entered Thessalonica he took note of the conventions and professional mores associated with public orators in framing the contours of his ministry.

\section{Paul's Autobiographical Account of his entry}

In 1 Thessalonians Paul refers to his عioodos within the context of a report that others outside Thessalonica had given (1:9). They have described the entry of Paul-'what manner of entry

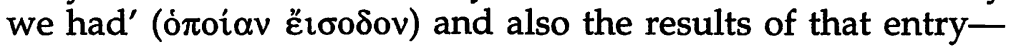

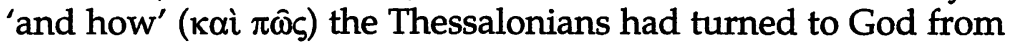
idols and abandoned their view of the eternity of the world in order to wait for His Son from heaven who would deliver them from the judgment of the Assize (1:10). Here two things were reported on-the nature of Paul's coming and its effects on his hearers.

The report of the manner of Paul's 'entry' is linked to $1: 5 \mathrm{~b}$ where he refers not only to the coming of the message of the gospel, but also what manner of people they proved to be

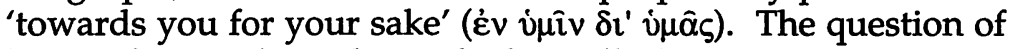
his professional conduct which is alluded to is taken up in

52Som. I.220.

${ }^{53} \mathrm{Agr} .13$.

${ }^{54}$ Her. 302.

${ }^{55}$ Det. 36, 45; cf. Mut. 10, Her. 2465, Congr. 129 and the discussion in Plato's day in G.B. Kerferd, op. cit., 62-3 and Philo and Paul, 88.

56Philo, Agr. 143. 
detail in 2:1ff. It is unfolded by him after he first records their response to the message (1:9-10), concluding it with an evaluation of the mission before proceeding to an explanatory statement of his professional conduct (2:2ff.). He reminds them of the effectiveness of the former before explicating on the latter which he introduces with the use of 'for' $(\gamma \alpha \dot{\rho} \rho)$ (2:1). While other public speakers might measure their success by passing the magic audience number of 17, the success of their pupils, and their public following, Paul assesses his coming to the Thessalonian brethren by declaring that it had not been in vain for they had changed their spiritual direction, their attitude to religion as service and their philosophical re-orientation of history (1:9-2:1). ${ }^{57} \mathrm{He}$ adds that his coming had not been preceded with an easy mission in Philippi, for there had been much suffering and rebuff (2:2).

Paul describes his professional conduct by means of the use of a number of contrasting positive and negative terms. 58 In 2:3 the 'exhortation' or 'encouragement' ( $\pi \alpha \rho \alpha \dot{\alpha} \lambda \eta \sigma \iota)$ ) is how Paul describes the effect of the gospel which he preached. It

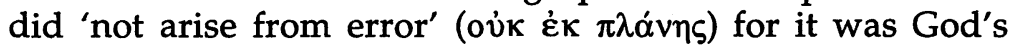
gospel, nor were there impure or immoral motives on his part

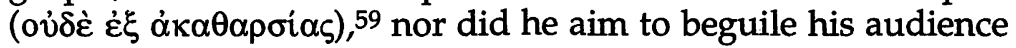
with trickery ( $\dot{\varepsilon} v \delta \dot{\lambda} \lambda \omega)$. By means of a positive statement he asserts 'but' ( $\dot{\alpha} \lambda \lambda \dot{\alpha})$ he was a tried and trustworthy servant

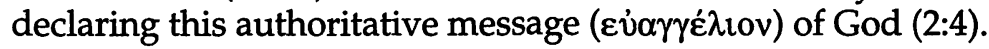

Furthermore, as he made known his message his intention had been to please God and not his audience (2:4b), for the God he seeks to please is the one who judges the motives of his messengers-'he tests their hearts'. There are three ways in

${ }^{57} \mathrm{Cf}$. Dio Chrysostom, Or. 31.30 on the sophists and also his pejorative comment on their being no more effectual than a eunuch, Or. 4.35.

${ }^{58}$ R. Jewett, op. cit., 151-2.

${ }^{59}$ The reference is unlikely to be 'grand' as against the 'plain' $\kappa \alpha \theta \alpha \rho$ ó style of speech, see Dionysius of Halicarnassus, Demonthenes 5. Philo, Det. 33-4 records verbatim, not only the first century philosophical justification by the sophists of their ethical conduct with the senses as the 'guards' and 'courtiers' of the soul (see R.T. Runia, Philo of Alexandria and the Timaeus of Plato (Leiden, E.J. Brill 1986) 306-8), but also their description of their success as 'men of mark and wealth. . .praised on all hands. . .revelling in luxurious and riotous living, knowing nothing of labour...' They claimed to teach virtue yet justified their immorality from which Paul dissociates himself here. 
which Paul believed he did not displease God, all of which are stated in negative ways.

He declares that neither he nor his assistant missioner were engaged in a flattering encomium, 'for neither at any time

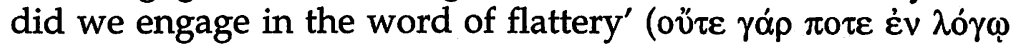

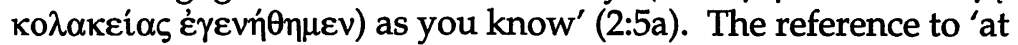
any time' $(\pi 0 \tau \varepsilon)$ could point not only to the actual entry

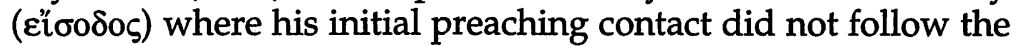
flattery convention associated with the encomium of the speech, but also to subsequent motivation in preaching. While it is usual to translate the term $\lambda$ ó ${ }^{\circ}$ s as 'word' the rendering of the term as 'rhetoric' is just as plausible, if not preferable, for he appears to have in mind the idea of the encomium with its required flattery of the audience.

While Paul makes only a succinct reference to flattery, a near contemporary, Dio Chrysostom, in his encomium in the third oration on kingship delivered before the emperor Trajan soon after his accession contains a long condemnation of the role of flattery, Or. 3.1-25. There he contrasts 'truth' ( $\dot{\alpha} \lambda \eta \theta \varepsilon i \alpha)$ and 'frankness' ( $\pi \alpha \rho \rho \eta \sigma i \alpha)$ with 'flattery' $(\theta \omega \pi \varepsilon i \alpha)$ and 'deceit' or 'guile' (á $\pi \alpha \dot{\tau} \tau)(3.12-13)$, being concerned that he himself might be open to a charge of flattery by his would-be detractors, and the emperor also accused of wanting to be praised, Or. 3.25. In an early oration on kingship he was to conclude the end of his encomium with the comment that this discourse of his oration ( $\lambda$ ó $\gamma \circ \varsigma$ ) will be delivered in all simplicity $(\dot{\alpha} \pi \lambda \hat{\omega} \varsigma)$

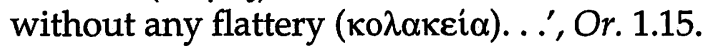

Paul also contended that he and his fellow worker

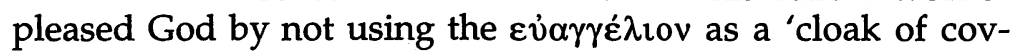
etousness ('́v $\pi \rho \circ \phi \alpha \dot{\sigma} \sigma \varepsilon l \pi \lambda \varepsilon 0 v \varepsilon \xi i \alpha \varsigma)$-God is witness'. Orators came promising to benefit their hearers culturally with public declamations or by educating their sons, to promote the welfare of the city with their benefactions and advice. However, there were very substantial pecuniary advantages for the orator from teaching pupils and from public lecturing. The term 'cloak of covetousness' was an apposite description. Their intention was to secure money from the hearers by means of flattery which ingratiated themselves with their audience. 60 Paul could affirm that he did not preach for financial gain.

${ }^{60}$ See Dio Chrysostom's point on this, Or. 3.19, 'the flatterer outdoes all, since he is the only perverter of truth'. 
He did not seek praise or glory ( $\delta$ ó $\xi \alpha)$ from the Christians or indeed from others. To whom does the latter refer? From the previous discussion in section (I) it can be said with some certainty that the seeking of praise and honour or glory by a speaker from non-Christian inhabitants of Thessalonica must refer to the orators and sophists. Speaking for the sake of personal glory and advancement would not be the way to please God (2:6a).

Paul continues his argument with the succinct statement that he can give proof of his genuineness. He did not

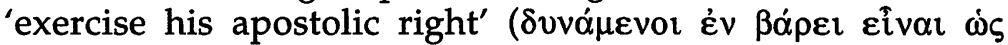

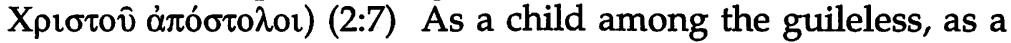
nurse cherishing her own children, he shared both the gospel and himself with the community-the message and the nonstatus messenger could not be separated (2:7-8).61 That Paul sought only their welfare and not his own could be further demonstrated by him. He engaged in labour and travail, working day and night so as not to impose on them as they preached the gospel of God (2:9). ${ }^{62}$

His conduct in Thessalonica was summed-up by him in three words, 'holy', 'righteous' and 'blameless' (2:10). That was how he operated in their midst as both they and God knew. He further describes this relationship with each one of them in warm filial terms as that of a father to children exhorting, encouraging and testifying so that they would walk worthily of God (2:10-11).

The $\varepsilon$ i $\sigma o \delta o \varsigma$ is then a quasi-technical term for Paul in that it refers not only to his actual coming, but also to his professional conduct as a gospel messenger who lives amongst those who accepted his message as the $\lambda$ ó $\gamma$ o of God. It is also clear that he describes his entry in an antithetical way. The force of his feelings can be more clearly appreciated from the way the passage is structured with its particles. Succinct negatives precede his positive self-description.

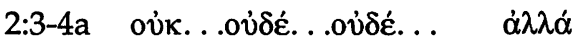

$2: 4 b$ ov̉x $\dot{\omega} s \quad \dot{\alpha} \lambda \lambda \dot{\alpha}$

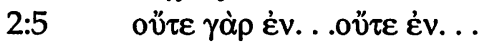

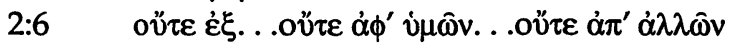

61J. Gillman, op. cit., 63.

${ }^{62} \mathrm{Cf}$. 1 Cor. 9 and my Philo and Paul ch. 8 for its relationship to the sophistic background. 
The examination of how Paul described his 'entry' gives rise to the question-with whom does he contrast his behaviour? In Dio's Alexandrian oration a similar contrast with other philosophers, poets, orators and sophists is drawn by Dio as the 'adviser' ( $\sigma \dot{v} \mu \beta o v \lambda \circ \varsigma)$ and 'saviour' ( $\sigma \omega \tau \eta \dot{\rho} \rho)$ of the city coming at the emperor's behest to effect a reconciliation, $O r$. 32.11-12. Unlike Dio's Alexandrian oration, the text of 1 Thessalonians 2 gives indication with whom the comparison is being made. While he uses functional analogies of a nurse caring for her offspring and a father nurturing and teaching his own $(2: 7,11)$, there is no evidence that Paul is contrasting himself with other Christian missionaries or teachers.

From the previous discussion in (I) and (II) it is concluded that a contrast is being made between his ethical conduct and that of other teachers who have come to Thessalonica. A more specific conclusion can be drawn that such teachers by implication sought glory and honour and praise as well as financial gain, and did so by deceptive means such as flattery. This description fits the characteristics and the life-style not of the first century philosophers but of the public orators and sophists and is supported by identical criticisms made primarily by Paul's own or near contemporaries.

\section{Anti-sophistic coming to Corinth (1 Cor. 2:1-5, 3:1ff.)}

As has been demonstrated, the convention of the coming of a public orator or sophist was well established in the ancient world. Do we have evidence elsewhere from the Pauline corpus of his interaction with these 'external' or secular orators? There is a similar 'coming' described by him in 1 Corinthians 2:1-5 which supports the above interpretation of 1 Thessalonians 2:112. In the former passage Paul provides an autobiographical account for the Corinthian community of his initial coming to that Roman colony. With respect to his arrival and ministry there he comments on three aspects of his 'coming' with the use

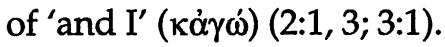

Firstly, he emphasizes to the community that 'and I coming to you, brethren, did not come preaching the mystery or testimony of God with superiority of rhetoric or wisdom'

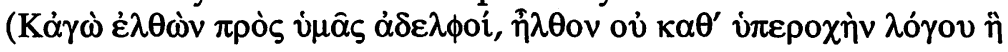




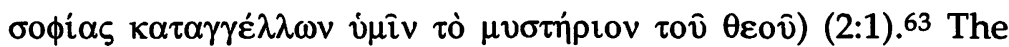
reason given was that the topic had already been determined by the preacher-Jesus and his crucifixion (2:1). Such a message required no rhetorical presentation lest, as Paul had previously explained, the cross of the Messiah be emptied of its saving power by means of oratory $(1: 17 \mathrm{~b})$.

Secondly, he further reflects on the relationship of rhetoric to his presentation. 'And I was with you in weakness and fear and much trembling'-hardly the virókpiois recommended by Philodemus in his lengthy discussion in his treatise on the rhetoric of 'bodily presence' with gestures and voice. 64 Further, his 'rhetoric' and preaching were not undertaken with persuasive rhetorical techniques. On the contrary, his message

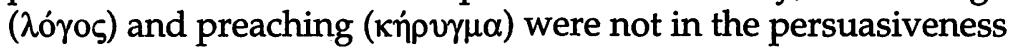
of wisdom. He did not engage in the 'demonstration' ( $\dot{\alpha} \pi \mathrm{o} \delta \varepsilon i \xi 1 \varsigma$ ) of 'proofs' ( $\pi i \sigma \tau \varepsilon 1 \varsigma)$ used by the orators in the 'art of persuasion' but by that of the Spirit and of power. The purpose of so doing was spelt out by Paul-so that the Christian's 'faith' or 'proof' ( $\pi i \sigma \tau \iota)$ ) would not rest in the wisdom of men i.e. the orators but in the power of God. 65

Thirdly, in 1 Corinthians 3:1ff. he gives an indication of the immature response of the Corinthians to him while he was there. He states 'and I, brethren, was not able ( $\dot{\delta} \delta v v \dot{\theta} \theta \eta v)$ to speak to you' (when I was there)-hence the use of the aoristas spiritual (3:1) because you were fleshly, babes in Christ'. At the time of his writing to the Corinthians that was still true (3:2). The reason for his saying this was that there was 'strife' and 'jealousy' in their midst. This reflects their carnality and their secular behaviour-they 'are walking according to man',

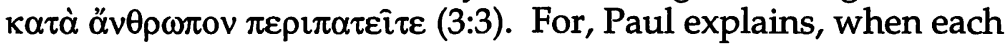
one of you is saying on the one hand 'I belong to Apollos' and on the other hand 'I belong to Paul' were they not behaving as secular men do? The significant issue in this passage apart from the secular perceptions the Corinthians had of the teach-

${ }^{63}$ The emphasis in the Greek text is on his coming and the methods he rejected.

64Philodemus, On Rhetoric I.195.xiv and cf. 2 Cor 10:10.

65For the detailed argument that Paul is refuting the three fold 'proofs' $\pi i \sigma \tau \varepsilon \iota \varsigma$ by which orators were taught to persuade their audience viz 'pathos', 'ethos' and 'demonstration' ( $\dot{\alpha} \pi 0 \delta \varepsilon i \xi \mathrm{i} \varsigma)$ as recommended in the rhetorical handbooks see my Philo and Paul, ch. 8. 
ing office of both former workers in their midst, is the fact that Paul indicates that even when he was in their midst their understanding of his work was influenced by secular categories. He was not seen as the employee of the Messiah and a steward of the mysteries of God (4:1). The modus operandi determined the message of the crucified God for Paul and not by the 'professional' conduct of first century orators. 66

\section{The Purpose of 1 Thessalonians 2:1-12}

In seeking to understand the purpose of Paul's writing 1 Thessalonians 2:1-12 two issues need to be explored. Firstly, 1 Corinthians 1:12-31 and 2:6-4:21 throws further light on the understanding of 1 Corinthians 2:1-5. Is there in 1 Thessalonians 1-3:13 a comparable discussion which might illuminate the reason for writing of 1 Thessalonians 2:1-12? Secondly, did the reason for raising this matter in 1 Thesssalonians 2:1-12 rest with the Thessalonians or with Paul and his present circumstances in Corinth or both? On the latter issue both matters are discussed in 1 Thessalonians 2:13ff. viz. their attitudes towards him (3:6) and his present distress and afflictions in Corinth (3:7).

Firstly, 1 Thessalonians 2:1-12 concludes with a statement of purpose, i.e. that the Thessalonians should walk worthily of God who had called them to his own kingdom and glory. Paul then proceeds with a further thanksgiving related to their reception of the gospel and their imitation of the Christian congregations in Judea with respect to suffering at the hands of their own people (2:13-16). He describes his emotions and events subsequent to his departure viz. his sense of loss at not seeing them (2:17-20), and his decision to send Timothy to consolidate their belief in the face of local antagonism which Paul had warned them to expect and his concern that they may not have withstood such pressure (3:1-5). He explains the relief that his fellow worker's return brought to him with the news of their faith and love and the personal joy that gave Paul in the midst of his own distress and affliction (3:6-8). His resulting thanksgiving is followed by the prayer that he might be able to return quickly (3:9-10a). The stated purpose of Paul's coming was to see them and to perfect what

66Philo and Paul, ch. 8. 
was lacking in their faith so that they may be established in their hearts blameless in holiness before God the Father and the Lord Jesus with all the saints at his coming (3:10b-13). 67 What Paul claimed for his own ministry while present $(2: 10)$ he seeks for in the ethical behaviour of Thessalonians.

From 1 Corinthians 1-4 we do know that Paul's problems related to the integrity of a continuing relationship with them and therefore demanded he use his original 'entry' policy to show that he did boast in the Lord (1:31). He did this within the discussion of their own spiritual needs and growth, which he argues, required him to exhort them as he did (1 Cor. 4:1421).68 Subsequent discussion in 1 Thessalonians 2:13-3:13 also encompasses both his concern for his ongoing relationships with them based on his impeccable professional conduct during his first entry, and his present and future concerns and provision for their spiritual formation related in part to his return to them.

Secondly, is it possible that a catalyst for 1 Thessalonians 2:1-12 was a problem Paul was encountering in Corinth at the time he was writing to the Thessalonians? He had entered Corinth with the same resolution on sophistic entries and ethics concerning his ministry as he had when he came to Thessalonica. We know that he was writing to them from the Corinth of whom he was to later record the Corinthian Christians' immaturity on this issue (1 Cor. 3:1ff.). He now wished to explain the entry and professional conduct of himself in Thessalonica in terms that would have explicated his enigmatic anti-sophistic stance. Was it that Paul wished to instruct the Thessalonians as a preventative measure so that they might not develop a similar secular perception of his ministry and thereby colour his ongoing relationship with them? Paul had no desire for his relationship to be hindered by the powerful, secular perception of a disciple to his orator or sophist. His second entry to Thessalonica or that of any other Christian teacher must not be identified or compared with orators because of the deleterious effects it would have on relationships and the integrity of the teaching ministry within the Christian community.

67For a discussion of the thanksgivings in 1 Thess. 2ff. see P.T. O'Brien, Thanksgiving in Paul (Leiden, E.J. Brill 1977) ch. 4.

68Philo and Paul, ch. 9. 
$\mathrm{He}$, like other first century observers, would have been well aware of the widespread growth, influence and importance of orators in a city-Favorinus tells us that in Corinth 'even the women and children' listened to him when he declaimed.69 The powerful sophistic movement and its dramatic effect on the East in the Claudian era was not destined to go away as was clear to his generation and subsequent ones.

Finally, if the Acts $17: 4 \mathrm{~b}$ evidence of the conversion to Christianity of leading members of the city is taken into account, then Paul's concern that they would be tempted to evaluate him in a secular fashion may not have been unfounded. The élite did this with the entry convention and ethical conduct of orators and often with a healthy scepticism towards the purity of their motives. Orators were known 'to sail away', leaving their pupils in the lurch. In P.Oxy. 930 there is a complaint that a pupil has been left by his teacher 'at the sixth book of The Iliad and the guardian is exhorted to find another quickly'. In P.Oxy. 2190 an orator left the countryside to seek his fortunes in the university city of Alexandria where he made pretentious claims for himself. Their attitude to orators who left their city could be fickle indeed, as was the case with Favorinus whose statue was cast down by the Corinthians to whom he writes seeking to secure good relationships once again. ${ }^{70}$ Was this customary fickleness towards those orators who left a city also one of the reasons for Paul's concern? The sharp, succinct contrasts Paul makes in 1 Thessalonians 2:3ff. suggests that there was a sense of urgency on his part to warn them against misjudging his ministry because of secular perceptions of him as a teacher. ${ }^{71}$ This would only damage his relationship with all the congregation.

69Dio Chrysostom, Or. 37.33.

70Ibid., Or. 37.16ff.

${ }^{71}$ The influence of oratory and orators in $\pi 0 \lambda \imath \tau \varepsilon i \alpha$ especially in the city's $\dot{\varepsilon} \kappa \kappa \lambda \eta \sigma i \alpha$ on the perception by members of the Christian $\dot{\varepsilon} \kappa \kappa \lambda \eta \sigma i \alpha$ of those who functioned as ministerial officers should not be underestimated for Gentile churches. For a recent discussion of this point in connection with the Philippian community see my "The Problem of "church" for the Early Church', in D. Peterson and J. Pryor (eds.), In the Fullness of Time: Biblical Studies in Honour of Archbishop Donald Robinson (Sydney, Anzea 1992) ch. 13 esp. 208-14. See also A.D. Clarke, Secular and Christian 


\section{Conclusions}

Paul's initial comings to Thessalonica and Corinth are described in terms that are clearly intended to show his deliberate renunciation of entry conventions and ethics of orators. It was a nascent or anticipated difficulty based on the behaviour of citizens towards orators in the first century which motivated Paul to write 1 Thessalonians 2:1-12. There appears to have been no internal wranglings or divisions in Thessalonica from the extant evidence. We have no intimation from the way Paul discusses Timothy's report (1 Thess. 3:6ff.) that it conveyed anything similar to that of Chloe's people which he was to record openly when he wrote to the whole Corinthian congregation (1 Cor. 1:11). The threat for the Thessalonians was an external one, and similar to that in Corinth. ${ }^{72}$ The sophistic tradition was to wreak havoc at a later period for Christians in the latter place but not for the Thessalonians as far as is known.

It is suggested in the light of the above evidence cited from non-biblical sources and the discussion of their resonances with 1 Thessalonians 2:1-12 that there is no need to posit a Pauline 'defence' against an attack by Jewish, Gnostic or Gentile Christian teachers as the reason for him writing it. It also rules out the need to cast around Paul in this passage the cloak of the ideal philosopher, whether it be in the $\mathrm{Cynic}^{73}$ or

Leadership in Corinth: A Socio-Historical and Exegetical Study of 1 Corinthians 1-6 (Leiden, E.J. Brill 1993)

${ }^{72} \mathrm{Cf}$. J. Barclay, 'Thessalonica and Corinth: Social Contrasts in Pauline Christianity', JSNT 47 (1992) 52-6 who argues for the external pressures as the source of difficulties for the Thessalonians but not for the Corinthians. ${ }^{73}$ Alleged Cynic influence which was the corner stone of the influential essay by A. Malherbe, "Gentle as a Nurse"; The Cynic Background to 1 Thessalonians 2', NovT 12 (1970) 203-17, esp. republished in Paul and the Popular Philosophers (Minneapolis, Fortress Press 1989) ch. 3. derived primarily from the Alexandrian oration of Dio Chrysostom, Or. 32. It needs to be now evaluated in the light of more recent scholarship which has refuted the old Hegelian Sophistic, Cynic, and philosophical understanding in his career, J.L. Moles, 'The Career and Conversion of Dio Chysostom', JRS 68 (1978) 79-100. The Alexandrian oration itself makes it quite clear that the discussion of the Cynics is restricted to \# 9, having discussed philosophers in general \# 8, and then the poets and orators \# 10. The oration is taken up primarily with the impact of the orators and sophists in Alexandria. Dio's orations cannot be divided into the three 
any other philosophical tradition. Why would Paul wish to identify himself with the philosophers? ${ }^{74}$ He believes he has adopted God's attitude towards the wise, including the philosopher, as he formulated his gospel strategy ( $c f .1$ Cor. 1:18ff. and his citation of the O.T. in 1:19 and 3:19-20).

Just as the sophists and orators in the Vespasian period were to receive financial incentives with exemption from liturgies and taxation and thus attract large numbers into the profession, 75 so too permission to charge hefty fees for forensic oratory in the Claudian Principate was to increase their numbers, activities and public profile. ${ }^{76}$ Philo provides evidence in this period of their increased activities,77 so too does 1 Thessalonians 2:1-12 in an indirect way.

Paul as a preacher had reflected not only on the use of classical rhetoric for the presentation of his message and rejected it. He also resolved in his own mind that it was highly inappropriate for the messenger of the gospel to adopt the

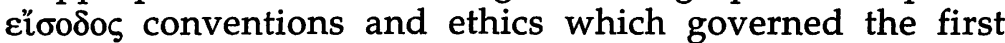
century orators and sophists on their initial visit to a city and their long term relationships with its citizens.

periods which had been suggested for his career, as Moles has now demonstrated. For a further discussion is my Philo and Paul, ch. 2.

${ }^{74}$ I.H. Marshall, 1 and 2 Thessalonians (Grand Rapids and London, Eerdmans and Marshall Morgan \& Scott 1983) 61.

75FIRA I. 73 (AD 74) cited N. Lewis and M. Reinholds, Roman Civilization Source Book II: The Empire (New York, Harper \& Row 1966) 295 and for its impact cf. P.Oxy. 2190 (Vespasian).

76Tacitus, Ann. 11.7, and G.A. Kennedy, op. cit., 437.

77Philo, Agr. 143. 